\title{
MEASURING THE SHADOW ECONOMY: ENDOGENOUS SWITCHING REGRESSION WITH UNOBSERVED SEPARATION
}

\section{Tomáš Lichard Jan Hanousek Randall K. Filer}
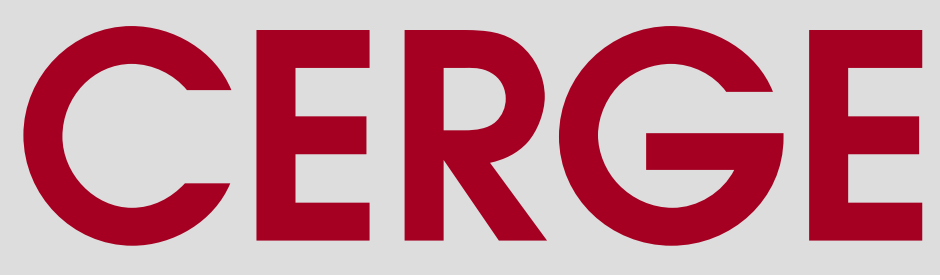


\title{
Working Paper Series 494 (ISSN 1211-3298)
}

\section{Measuring the Shadow Economy: Endogenous Switching Regression with Unobserved Separation}

\author{
Tomáš Lichard \\ Jan Hanousek \\ Randall K. Filer
}

CERGE-EI

Prague, October 2013 
ISBN 978-80-7343-298-0 (Univerzita Karlova. Centrum pro ekonomický výzkum a doktorské studium)

ISBN 978-80-7344-290-3 (Akademie věd České republiky. Národohospodářský ústav) 


\title{
Measuring the Shadow Economy:
}

\section{Endogenous Switching Regression with}

\section{Unobserved Separation*}

\author{
Tomáš Lichard ${ }^{1}$, Jan Hanousek ${ }^{1}$, and Randall K. Filer ${ }^{1,2}$ \\ ${ }^{1}$ CERGE-EI, Prague, Czech Republic ${ }^{\dagger}$ \\ ${ }^{2}$ Department of Economics, Hunter College and the Graduate Center, CUNY; IZA, Bonn and CESifo, \\ Munich
}

\begin{abstract}
We develop a novel estimator of unreported income, perhaps due to tax evasion, that does not depend on as strict identifying assumptions as previous estimators based on microeconomic data. The standard identifying assumption that the selfemployed underreport income whereas wage and salary workers do not is likely to fail in countries where employees are often paid under the table or have a secondary source of self-employed income. Assuming that evading individuals have a higher consumption-income gap than non-evading ones due underreporting both to tax authorities and in surveys, an endogenous switching model with unknown sample separation enables the estimation of consumption-income gaps for both underreporting and truthful households. This avoids the need to identify non-evading and evading groups ex ante. This methodology is applied to data from Czech and Slovak household budget surveys and shows that estimated evasion is substantially higher than found using previous methodologies.
\end{abstract}

Keywords: endogenous switching regression, shadow economy, tax evasion, underreporting

JEL classification: C34, H26

\footnotetext{
${ }^{\dagger}$ CERGE-EI is a joint workplace of the Center for Economic Research and Graduate Education, Charles University in Prague, and the Economics Institute of the ASCR, v.v.i.

* This project was supported by the National Science Foundation of the United States under grant \#SES-0752760 to the Research Foundation of the City University of New York. All opinions are those of the authors and should not be attributed to the NSF or CUNY. Support from the grant SVV-2013-267 801 is also gratefully acknowledged. We wish to express thanks for valuable comments to Orley Ashenfelter, Richard Blundell, Libor Dušek, Štěpán Jurajda, Peter Katuščák, Jan Kmenta, Steven Rivkin, Karine Torosyan and seminar participants at CERGE-EI. All remaining errors and omissions are entirely ours.
} 


\begin{abstract}
Abstrakt
Vyvinuli jsme odhad nereportovaného příjmu (pravděpodobně svázaného s daňovými úniky), který využívá mikroekonomických dat a který není založený na tak přísných předpokladech jako předchozí odhady. Standardní předpoklad, že samostatně výdělečně činné osoby nepřiznávají část př́ijmu, zatím co zamě-stnanci tuto možnost nemají, může selhat v zemích, kde je relativně časté platit část mzdy hotově bez dokladu, nebo kde mají zaměstnanci více zdrojů prríjmu. Pokud předpokládáme, že jednotlivci s nepřiznanými příjmy mají vyšší rozdíl mezi spotřebou a př́imem než ti, kteří svůj př́ijem přiznávají, můžeme odhadovat tento rozdíl pro obě skupiny. Využíváme přitom regresní model s přechodem mezi dvěma stavy (přiznaný a zatajovaný př́jem), kde pravidlo přechodu není plně známé a je endogenní (endogenous switching model with unknown sample separation rule). Tím se vyhneme potřebě rozdělit domácnosti do těchto skupin ex ante. Tato metodologie aplikovaná na českých a slovenských rodinných účtech vede k vyšším odhadům šedé ekonomiky jako předchozí mikroekonomické metodologie.
\end{abstract}




\section{Introduction}

Contrary to the folk wisdom that "what you don't know don't hurt you, for it ain't real,"1 the shadow economy is very real and not knowing its size and composition accurately can seriously damage the design and implimentation of public policy. It is impossible to estimate the magnitude of the deadweight loss (Harberger, 1964) from tax systems or economic regulations without considering the diversion of economic activity into a less efficient hidden sector. ${ }^{2}$ Countries that try to offset the income lost to tax evasion by increasing tax rates can find themselves in a "vicious cycle" (Lyssiotou, Pashardes, \& Stengos, 2004, p.622) where rising tax rates create incentives for even greater evasion. Changes in the propensity to hide income can account for the empirical observation that estimates of the elasticity of labor supply in response to tax increases are close to zero while those of the elasticity of taxable income with respect to the same tax increases range from 0.25 up to 2.0 (see Saez, Slemrod, \& Giertz, 2012).

Dreher, Méon, and Schneider (2014) show that once corrections are made for the size of the unreported economy, the link between institutional quality and output is much weaker than when using reported income. In other words, weak institutions may not hamper economic productivity so much as divert output from recorded to unrecorded channels. Elgin and Uras (2013)find that a larger shadow economy increases public debt and the probability of sovereign default. Additionally a loss of social welfare may arise because inaccurately reported incomes inhibit implementation of "first-best" social assistance programs by systematically violating the principle of treating equals equally, undermining public support for otherwise desirable policies. Globally, allocations of foreign assistance and investment capital flows may be distorted by biased estimates of per capita income and its growth rate. Each of these factors, and more, make it of critical policy importance that we obtain accurate estimates of the size, change in size, and distribution of the shadow economy across countries and over time.

\footnotetext{
${ }^{1}$ This phrasing is from Jack Burden, the narator of Robert Penn Warren's "All the King's Men" Warren (1946).

${ }^{2}$ Such inefficiencies might be caused by resources being used in evasion efforts instead of in productive activities. They might also arise because the need not to draw attention from authorities results in inefficiently small enterprise sizes.
} 
Allingham and Sandmo (1972) provided a basic framework for rigorously thinking about the shadow economy theoretically, but estimating the size of the shadow economy empirically has proven difficult for numerous reasons, not the least of which is that by definition individuals are attempting to hide such activities. Schneider and Enste (2002) divide the methods of estimation into two main groups: direct and indirect. The first group is composed of surveys and other inquiries regarding tax evasion. It is hard to imagine, however, that individuals who do not report all or part of their income on tax returns would reveal their full income in a survey, even if the survey promises anonymity. If nothing else, memories or records of income reported to the tax authorities provide an easy reference point when answering survey questions. In another direct method, tax authorities in many countries attempt to estimate tax evasion from audited tax returns. ${ }^{3}$

In the second group (indirect methods) Schneider and Enste recognize three main subgroups:

1. national accounting approaches focusing on the discrepancy between national accounting source and use data (the so-called "macroeconomic approach") or the discrepancy between reported incomes and expenditures of households ("microeconomic approach");

2. monetary approaches focusing on cash velocity, and transaction demand; and

3. physical input methods focusing on electricity consumption.

All such methods rely on what Slemrod and Weber (2012) aptly refer to as "traces of true income." Frequently several indirect indicators of the size of the shadow economy are combined in a single estimating equation, the so called Multiple Indicators-Multiple Causes (MIMIC) technique. Field and laboratory experiments (see Slemrod, Blumenthal, \& Christian, 2001) can also be included as a possible means of measurement.

Macroeconomic methods of estimating the size of the shadow economy have a long tradition dating from Cagan (1958), but have often been criticized for lacking an underlying theory and for flawed econometric techniques (see Hanousek \& Palda, 2006 or Thomas,

\footnotetext{
${ }^{3}$ One of the most comprehensive examples is probably the US Tax Compliance Measurement Program (TCMP). See Slemrod (2007) for details.
} 
1999). The assumption of constant velocity of money implied in many papers using the monetary method is suspect, while changes in electricity demand inherently confound changes in the size of the shadow economy with changes in the composition of output or production efficiency. Microeconomic methods, on the other hand, are somewhat less common although more prevalent that indicated by Schneider (2014), who refers to them in a single footnote.

A key difficulty with prior work using households' reported income and expenditure is the need for an a priori assumption used to identify a subset of the population who are assumed not to evade (typically wage and salaried workers), thereby leaving all hidden income to be attributed to the rest of the sample (especially the self-employed or farmers). This simplifying assumption is, however, weak both theoretically (see Kolm \& Nielsen, 2008 for a model that includes concealment of income by firms and salaried workers) and empirically. Analysis of the 2007 Eurobarometer survey (Williams, 2013) finds that 5.5 percent of respondents in the EU admit that they received unreported "envelope" wages over and above their reported wages from their formal employer in the preceding 12 months. National values of the percentage reporting that some wages from their main employer went unreported range substantially, from a high of 23 percent in Romania to a low of 1 percent in France, Germany, Luxembourg and the UK. The Czech and Slovak Republics, which we will analyze below, are at 3 and 7 percent, respectively. Among those receiving envelope wages, the share of gross income reported as undeclared also varied substantially, ranging from 10 percent in the UK to 86 percent in Romania. The Czech Republic and Slovakia stand at 14 and 17 percent. ${ }^{4}$ For the three Baltic countries Putniņš and Sauka (2014) report that such undeclared employee wages range from 10 to 16 percent of total economic activity

In a pioneering work, Pissarides and Weber (1989) use self-employment to identify households that might under-report income. They estimate food Engel curves for the employed from the UK 1982 family expenditure survey and then invert these to predict in-

\footnotetext{
${ }^{4}$ These numbers, however, should be taken only as an indication. As the European Commission, 2007 phrased it: "In view of the sensitivity of the subject, the pilot nature of the survey and the low number of respondents who reported having carried out undeclared work or having received 'envelope wages', results should be interpreted with great care" (p.3).
} 
come for the self-employed. The difference between the predicted income and the reported income of the self-employed is interpreted as the size of the "black economy." Lyssiotou et al. (2004) criticized this approach, claiming that the use of food expenditures only can cause preference heterogeneity to be interpreted as tax evasion, and suggested estimating a complete demand system to account for the heterogeneity in preferences using the generalized method of moments (GMM). Their approach is, however, still limited by the $a$ priori assumption that wage income is always reported correctly. ${ }^{5}$

Additional work that identifies under-reporting based on self-employment status includes Hurst, Li, and Pugsley (2014), Ekici and Besim (2014), Kukk and Staehr (2014), Engström and Holmlund (2009), Kim, Piger, and Startz (2008) and Schuetze (2002). ${ }^{6}$ Tedds (2010) criticized this line of inquiry on three main grounds: (1) that it assumed constant fraction of under-reporting on total income; (2) it assumed a specific form of the under-reporting function; and (3) it relied on monotonicity of the expenditure function with respect to income. ${ }^{7}$ As a remedy Tedds (2010) used a non-parametric estimation of food Engel curves. This estimation strategy, however, still hinges on the assumption that only self-employed individuals evade.

Braguinsky, Mityakov, and Liscovich (2014) also argue that a large portion of employee income in Russia (especially in trade and services sector where cash flows are easier to manipulate) is hidden from the authorities. In a novel approach they use data on new car ownership matched with data on incomes from a different source and estimate that 80 percent of total earnings of car-owning employees is unrecorded. They also rely, however, on an a priori and ad hoc mechanism for assigning evading probability, although in this case based on a worker's sector of employment and the ownership structure of his or her firm. Martinez-Lopez (2012) still relies on the classical Pissarides and Weber method for separating workers in evading and non-evading, but cleverly compares results across several alternative assumptions about who does not evade to obtain a hint regarding the

\footnotetext{
${ }^{5}$ See also Gunes, Starzec, and Gardes (2013) for an effort to use estimates of a complete demand system to measure the size of the shadow economy.

${ }^{6}$ Davutyan (2008) uses a highly related division scheme based on formal and informal employment.

${ }^{7}$ The last criticism applies specifically to Lyssiotou et al. (2004) who used a complete demand system. Goods that were shown to violate this assumption include alcohol and tobacco.
} 
possibility of evasion in the "non-evasion" group.

Studies that estimate the evasion response to tax changes can provide added insight. Gorodnichenko, Martinez-Vazquez, and Sabirianova Peter (2009) used the 2001 flat tax reform in Russia as a natural experiment that produced a "control group" consisting of part of the population for whom the marginal tax rate did not change whose income under-reporting (also assumed unchanged) could be compared with a "treatment group" of individuals for whom the marginal tax fell. As a result, they did not need the ex ante assumption about which groups of individuals evade. They, however, can estimate only the change in the shadow economy, not its overall size.

We propose to avoid the problem of arbitrary a priori assignment of individuals to evading and non-evading groups by estimating an endogenous switching regression with an unknown sample separation rule. Such a technique has not previously been applied to the shadow economy, ${ }^{8}$ although it has often been used in other contexts In an early study, Dickens and Lang (1985) used such a model to test the theory of dual labor markets. ${ }^{9}$ Two more recent papers applied this methodology to family economics. Arunachalam and Logan (2006) incorporated two competing, unobservable incentives for offering a dowry (passing assets to the daughter and her family or acquiring a more desirable husband for their daughter) into a switching regression model, while Kopczuk and Lupton (2007) studied whether having a positive net worth at the time of death implies a bequest motive.

Other examples of the application of switching regressions with an unknown (or partially known) sample separation rule include the estimation of cartel stability by Lee and Porter (1984) and stochastic frontier models by Douglas, Conway, and Ferrier (1995), or Caudill (2003). These studies have established the feasibility of maximum likelihood and other estimation techniques in this situation.

\footnotetext{
${ }^{8}$ DeCicca, Kenkel, and Liu (2010) use an endogenous switching regression to estimate the effect of state differences in cigarette excise taxes on the probability of cross-border cigarette purchases in the US. Their model, however, relies on an observable rather than unobservable separation rule since they know which purchases were made across a border.

${ }^{9}$ Since then, this methodology has been used regularly to study dual labor markets theory in various contexts. See e.g. Alzua (2009).
} 


\section{Methodology}

\subsection{Consumption-income gap}

Our analysis relies on the consumption-income gap as described by Gorodnichenko et al. (2009) based on three assumptions coming from the permanent income hypothesis (Friedman, 1957):

$$
\begin{aligned}
Y_{i}^{R} & =\Gamma_{i} Y_{i}^{c}, \text { where: } \Gamma_{i}=\Gamma\left(\mathbf{S}_{i}\right)=\exp \left(-\mathbf{S}_{i} \boldsymbol{\gamma}+\text { error }\right) \\
Y_{i}^{C} & =H_{i} Y_{i}^{P}, \text { where: } H_{i}=H\left(\mathbf{L}_{1, i}\right)=\exp \left(\mathbf{L}_{1, i} \boldsymbol{\eta}+\text { error }\right), \\
C_{i} & =\Theta_{i} Y_{i}^{P}, \text { where: } \Theta_{i}=\Theta\left(\mathbf{L}_{2, i}\right)=\exp \left(\mathbf{L}_{2, i} \boldsymbol{\theta}+\text { error }\right)
\end{aligned}
$$

where $i$ denotes households. Equation(1) defines reported income as a fraction $\Gamma$ of true income, where $\Gamma$ is a function of household characteristics affecting under-reporting $\left(\mathbf{S}_{i}\right)$. In estimates presented below this vector includes age (older people are more risk averse and, therefore, less prone to tax evasion), education, whether workers in the household are self-employed, working in a large or small firm (small firms are more prone to save labor costs by paying a low "official" wage combined with a part of the wage paid "under the table"), or employed in the public or private sector (government is usually less likely to pay its employees "under the table", although on the other hand, public employees may be more prone to accepting bribes).

Equation(2) is based on the permanent income hypothesis, where the current true income is a fraction $H_{i}$ of the permanent lifelong income. $H_{i}$ depends on the current stage of the life cycle of the head of the household and his or her spouse including their ages, education and work experience (vector $\mathbf{L}_{1, i}$ ). Equation (3) indicates that consumption constitutes a fraction $\Theta_{i}$ of the household's permanent income. The characteristics $\mathbf{L}_{2, i}$ affecting a household's consumption patterns (tastes) include the age of the head of the household and spouse, number and ages of children, number of other household members, marital status, and education among others. Taking logarithms of (1), (2) and (3) and 
substituting yields a definition of the consumption-income gap:

$$
\log C_{i}-\log Y_{i}^{R}=\mathbf{S}_{i} \boldsymbol{\gamma}+\mathbf{L}_{i} \boldsymbol{\alpha}+\varepsilon_{i}
$$

where $\log C_{i}-\log Y_{i}^{R}$ is the consumption-income gap of the household. Note that if all other household characteristics are held equal, a higher consumption-income gap implies a higher degree of under-reporting.

As in Gorodnichenko et al. (2009), our basic definition of consumption is the expenditure on non-durable goods. We focus on non-durables because reporting of large purchases of durables may be more less reliable than reporting of smaller, regular non-durable consumption. A household may be inclined to hide larger purchases of durables out of caution or fear, especially if it participates in the informal sector. Moreover, purchases of durable goods are more likely than other expenditures actually to be investment, especially if the household derives part of its income from self-employment. By limiting the measure of consumption to non-durables, however, we make an assumption that preferences over non-durable and durable goods are homothetic, implying that the income elasticity of non-durable goods is unitary. This assumption has often been used in macroeconomic literature (see Eichenbaum \& Hansen, 1990; Ogaki \& Reinhart, 1998; or Gorodnichenko et al., 2009), although Pakoš (2011) contains a critique. Even Pakoš' estimate of the income elasticity of non-durable goods is, however, close to 1.0, lying in the interval [0.882, $0.954]$.

A second possible problem with basing estimates on non-durable consumption is that such consumption may include tax deductible purchases for self-employed individuals. This is usually not the case with food as used by Pissarides and Weber (1989). On the other hand, expenditures on food may not meet the homotheticity requirement. We will, therefore, report results based on both food and total non-durable consumption and find these to be gratifyingly consistent, suggesting that neither of these potential problems is critical. 


\subsection{From consumption-income gap to shadow economy}

Without much loss of generality we can assume that there are two groups of individuals in every economy: those who evade and those who do not. These two groups of agents differ, all other characteristics held constant, by the average size of the gap between their income and consumption. For non-evaders, $\gamma$ in Equation (4) is equal to 0 by definition. Since consumption is based on true rather than reported income, evading households will report consuming a greater share of their income. Under the assumption that, unlike income, consumption is measured more (and equally) accurately for both groups (for support of this assumption see Hurst et al., 2014; Kreiner, Lassen, \& Leth-Petersen, 2013; Meyer \& Sullivan, 2013; Brewer \& O’Dea, 2012; and Brzozowski \& Crossley, 2011), we can write:

$$
\begin{array}{cl}
\log C_{i}-\log Y_{i}^{R, e}=\mathbf{S}_{i} \boldsymbol{\gamma}+\mathbf{L}_{i} \boldsymbol{\alpha}_{e}+\varepsilon_{e, i} & \text { if } i \text { is evading, } \\
\log C_{i}-\log Y_{i}^{R, n e}=\mathbf{L}_{i} \boldsymbol{\alpha}_{n e}+\varepsilon_{n e, i} & \text { if } i \text { is not evading, }
\end{array}
$$

where $Y_{i}^{R, e}$ and $Y_{i}^{R, n e}$ are the reported income if the household $i$ evades and does not evade, respectively. It is reasonable to assume that agents evade if their expected gain from evasion exceeds a certain threshold $f$ :

$$
\left(\log C_{i}-\log Y_{i}^{R, e}\right)-\left(\log C_{i}-\log Y_{i}^{R, n e}\right) \geq f_{i}
$$

where $f_{i}$ represents the costs of evasion including expected fines and costs associated with hiding income (including psychic costs such as risk or dishonesty aversion) of household $i$. One can think of Equation (7) as the reduced form of an underlying optimization problem. In this equation, agents compare the maximal net benefits from the optimal level of under-reporting with those from reporting incomes accurately.

If we assume that the cost of evasion is equal to a constant average cost $k$ plus an error term $\varepsilon_{f, i}$ (the deviation of household $i$ from this average) we can write the probability of household $i$ being in the evading regime as:

$$
P=\operatorname{Pr}\left\{\mathbf{S}_{i} \boldsymbol{\gamma}+\mathbf{L}_{i}\left(\boldsymbol{\alpha}_{e}-\boldsymbol{\alpha}_{n e}\right)-k \geq \varepsilon_{f, i}+\varepsilon_{e, i}-\varepsilon_{n e, i}\right\}=\operatorname{Pr}\left\{\mathbf{Z}_{i} \delta \geq \varepsilon_{s, i}\right\}
$$


For estimating purposes, this system can be expressed as follows:

$$
\begin{aligned}
\left(\log C_{i}-\log Y_{i}^{R}\right)_{e} & =\mathbf{X}_{i} \boldsymbol{\beta}_{e}+\varepsilon_{e, i}, \\
\left(\log C_{i}-\log Y_{i}^{R}\right)_{n e} & =\mathbf{X}_{i} \boldsymbol{\beta}_{n e}+\varepsilon_{n e, i}, \\
y_{i}^{*} & =\mathbf{Z}_{i} \boldsymbol{\delta}-\varepsilon_{s, i}, \\
\log C_{i}-\log Y_{i}^{R} & = \begin{cases}\left(\log C_{i}-\log Y_{i}^{R}\right)_{e} & \text { iff } y_{i}^{*} \geq 0, \\
\left(\log C_{i}-\log Y_{i}^{R}\right)_{n e} & \text { iff } y_{i}^{*}<0,\end{cases}
\end{aligned}
$$

where $\mathbf{X}_{i}$ is the vector of explanatory variables that affect consumption and income and $\mathbf{Z}_{i}$ is the vector of variables that affect the tax evasion propensity.

The latent variable $y_{i}^{*}$ can be interpreted as the propensity to evade. It cannot be observed, but if $y_{i}^{*}>0$ (i.e. the household decides to evade), household $i$ 's gap is determined by Equation(9). If $y_{i}^{*}<0$, the household does not want to evade and its consumption-income gap is determined by Equation(10). ${ }^{10}$ Alternatively, the same setup can be justified intuitively by thinking about the household decision as a two-step procedure: first, the household decides if it wants to evade at all, and then, conditional on having decided to evade, it decides about the amount to hide.

We can express the likelihood contribution of household $i$ as:

$$
\begin{aligned}
L_{i} & =\operatorname{Pr}\left(\varepsilon_{s, i} \leq \mathbf{Z}_{i} \boldsymbol{\delta} \mid \mathbf{Z}_{i}, \mathbf{X}_{i}, \varepsilon_{e, i}\right) \cdot f\left(\varepsilon_{e, i}\right) \\
& +\operatorname{Pr}\left(\varepsilon_{s, i}>\mathbf{Z}_{i} \boldsymbol{\delta} \mid \mathbf{Z}_{i}, \mathbf{X}_{i}, \varepsilon_{n e, i}\right) \cdot f\left(\varepsilon_{n e, i}\right)
\end{aligned}
$$

\footnotetext{
${ }^{10}$ This idea is, of course, well known in many areas of applied economics. For example, recall the propensity to work in estimation of labor supply. Hours worked, just as hidden income in our case, are non-zero if and only if $y^{*}>0$, leading to a distribution censored at 0 .
} 
If we assume that $\left(\varepsilon_{e}, \varepsilon_{n e}, \varepsilon_{s}\right) \sim N(0, \Sigma),{ }^{11}$ where:

$$
\Sigma=\left(\begin{array}{ccc}
\sigma_{e}^{2} & & \\
\sigma_{e, n e} & \sigma_{n e}^{2} & \\
\sigma_{e, s} & \sigma_{n e, s} & 1
\end{array}\right)
$$

the log-likelihood function (13) becomes:

$$
\begin{aligned}
\ln L\left(\boldsymbol{\beta}_{e}, \boldsymbol{\beta}_{n e}, \delta, \sigma_{e}, \sigma_{n e}, \sigma_{e, s}, \sigma_{n e, s}\right) & =\sum_{i=1}^{N} \ln \left\{\frac{1}{\sigma_{e}} \Phi\left(\frac{\mathbf{Z}_{i} \boldsymbol{\delta}-\frac{\sigma_{e, s}}{\sigma_{e}^{2}} \varepsilon_{e, i}}{\left(1-\frac{\sigma_{e, s}^{2}}{\sigma_{e}^{2}}\right)^{.5}}\right) \cdot \phi\left(\frac{\varepsilon_{e, i}}{\sigma_{e}}\right)\right. \\
& \left.+\frac{1}{\sigma_{n e}}\left[1-\Phi\left(\frac{\mathbf{Z}_{i} \boldsymbol{\delta}-\frac{\sigma_{n e, s}}{\sigma_{n e}^{2}} \varepsilon_{n e, i}}{\left(1-\frac{\sigma_{n e, s}^{2}}{\sigma_{n e}^{2}}\right)}\right)\right] \cdot \phi\left(\frac{\varepsilon_{n e, i}}{\sigma_{n e}}\right)\right\},
\end{aligned}
$$

where $\phi(\cdot)$ and $\Phi(\cdot)$ are the standard normal density and the cumulative distribution functions respectively, and:

$$
\begin{aligned}
\varepsilon_{e, i} & =\left(\ln C_{i}-\ln Y_{i}\right)-\mathbf{X}_{i} \boldsymbol{\beta}_{e} \\
\varepsilon_{n e, i} & =\left(\ln C_{i}-\ln Y_{i}\right)-\mathbf{X}_{i} \boldsymbol{\beta}_{n e} .
\end{aligned}
$$

Note that, as usual in this type of estimation, $\sigma_{e, n e}$ is unidentified, as the two regimes never occur at the same time (see Maddala, 1983). Technical details of the maximization of Equation(14) are given in the Appendix. For robustness purposes we employ several different identification strategies. It is generally desirable to find exclusion restrictions such that $\mathbf{Z}_{i} \neq \mathbf{X}_{i}$, thereby ensuring that all other parameters (except $\sigma_{s}$, which is normalized to 1) are identifiable. We use two sets of such restrictions, one that excludes self-employment and public sector employment from $\mathbf{Z}_{i}$ and a second that adds employment in a blue-collar occupation (and a white collar occupation for the spouse of the household head) to the excluded variables. Finally, given that the model is highly

\footnotetext{
${ }^{11}$ This assumption is reasonable if the distributions of income and consumption are both log-normal (see Equations(1)-(3)). Evidence from various countries shows that a log-normal distribution is a good approximation of empirical distribution of income (especially up to 98 th percentile - see e.g. Clementi \& Gallegati, 2005) This holds for our data as well.
} 
nonlinear, we also estimate it identified strictly off of its functional form.

\subsection{Measure of the shadow economy}

Under the initial assumption of correct consumption reporting, the expected value of the difference in the gaps for both regimes of household $i$ is equal to:

$$
\mathbb{E}\left[\left(\log \widehat{C_{i}-\log } Y_{i}^{R}\right)_{e}-\left(\log \widehat{C_{i}-\widehat{\log } Y_{i}^{R}}\right)_{n e}\right]=\mathbb{E}\left[\left(\log \widehat{Y_{i, n e}^{R}-\log } Y_{i, e}^{R}\right)\right],
$$

which is household $i$ 's estimated degree of income under-reporting as a fraction of its reported income. The overall size of the shadow economy is therefore defined as the expected value of this difference in gaps, i.e., the sum of the differences between the income-consumption gaps for the respective regimes weighted by the probability of each household being in the shadow sector:

$$
\widehat{\text { Evasion }}=\frac{1}{N} \sum_{i=1}^{N}\left(\mathbf{X}_{i} \hat{\boldsymbol{\beta}}_{e}-\mathbf{X}_{i} \hat{\boldsymbol{\beta}}_{n e}\right) \cdot \hat{P}_{e, i}
$$

The probability of being in the shadow sector $\hat{P}_{e, i}$ can be computed by Bayes' theorem as:

$$
\hat{P}_{e, i}=\frac{\frac{1}{\hat{\sigma}_{e}} \Phi\left(\frac{\mathbf{z}_{i} \hat{\boldsymbol{\delta}}_{-}-\frac{\hat{\sigma}_{e, s}}{\hat{\sigma}_{e}^{2}} e_{e, i}}{\left(1-\frac{\hat{\sigma}_{e, s}^{2}}{\hat{\sigma}_{e}^{2}}\right)^{.5}}\right) \phi\left(\frac{e_{e, i}}{\hat{\sigma}_{e}}\right)}{\frac{1}{\hat{\sigma}_{e}} \Phi\left(\frac{\mathbf{z}_{i} \hat{\boldsymbol{\delta}}-\frac{\hat{\sigma}_{e, s}}{\hat{\sigma}_{e}^{2}} e_{e, i}}{\left(1-\frac{\hat{\sigma}_{e, s}^{2}}{\hat{\sigma}_{e}^{2}}\right)^{.5}}\right) \phi\left(\frac{e_{e, i}}{\hat{\sigma}_{e}}\right)+\frac{1}{\hat{\sigma}_{n e}}\left[1-\Phi\left(\frac{\mathbf{z}_{i} \hat{\boldsymbol{\delta}}-\frac{\hat{\sigma}_{n e, s}}{\sigma_{n e}^{2}} e_{n e, i}}{\left(1-\frac{\hat{\sigma}_{n e, s}^{2}}{\hat{\sigma}_{n e}^{2}}\right)^{.5}}\right)\right] \cdot \phi\left(\frac{e_{n e, i}}{\hat{\sigma}_{n e}}\right)},
$$

where:

$$
\begin{aligned}
e_{e, i} & =\left(\ln C_{i}-\ln Y_{i}\right)-\mathbf{X}_{i} \hat{\boldsymbol{\beta}}_{e}, \\
e_{n e, i} & =\left(\ln C_{i}-\ln Y_{i}\right)-\mathbf{X}_{i} \hat{\boldsymbol{\beta}}_{n e} .
\end{aligned}
$$


Equation(18) will thus give the size of the shadow economy as a fraction of an economy's officially reported income.

To increase the robustness to the choice of initial values and the presence of outliers, Monte Carlo simulations were used to compute both means and standard errors of the estimators. For each country, 250 random samples with replacement were drawn from the data, with the estimation of Equation (14) and a computation of the shadow economy from Equations (18) and (19) done for each sample. ${ }^{12}$ These maximizations result in a data series from which the means of the estimates can be computed. Standard errors are then the standard errors of these estimated means.

\section{Data}

We illustrate the value of our estimator by applying it to recent data from the Czech and Slovak Republics. The choice of these countries is not arbitrary. Rather, they represent modern, EU member economies with the required data collected by Eurostat standards where the assumption that only self-employed households hide income (as assumed by Pissarides \& Weber, 1989) and numerous others seems particularly questionable. In both countries we use the Household Budget Survey from 2008.

\subsection{Czech Republic}

The data from the Czech household budget survey for 2008 contain information about income from various sources and expenditures on different categories of goods and services for 3,271 Czech households. We restrict our analysis to a subsample of 2138 households with working heads. ${ }^{13}$ Summary statistics (weighted means) for this subsample are given in Table 1. The definition of disposable income is the monthly average of the total gross income of the household from all sources minus all taxes and obligatory payments (such as health insurance, which is technically a tax in the Czech Republic). To account for possible

\footnotetext{
${ }^{12}$ See Appendix A for details. Sample draws that failed to converge were dropped from the data (see note 17 below).

${ }^{13}$ The reduction in sample size is primarily due to the presence of households headed by retirees.
} 
consumption smoothing and precautionary saving (which may be greater for certain types of households), net dissavings were included in income. We define consumption as the sum of expenditures on non-durable goods, more specifically, expenditure on food both at home and away from home, alcohol and tobacco, ${ }^{14}$ clothing and footwear, rents, utilities and other services. As discussed above, controls include dummies for public sector or self-employment status of the head of household or spouse, blue-collar employment of the head or spouse, ${ }^{15}$ white collar employment of the spouse, age of the household head, square of age (previous research shows that risk aversion increases with age but perhaps at a declining rate (see Guiso, Sapienza, \& Zingales, 2013) and education of the household head.

\subsection{Slovak Republic}

As in the Czech case, the Slovak household budget survey for 2008 was used. Overall, the sample contains 4,718 households. Estimation was done on a subsample of 2,991 households whose head was working (either employed or self-employed) during 2008. Summary statistics for Slovak households included in the subsample can be seen in Table 2. The definitions of variables are almost an exact copy of those of their Czech counterparts, except for marital status, which is explicitly observed in the Slovak data.

\section{Results}

As discussed above, the system of Equations (9) - (12) was estimated using Monte Carlo methods. Structural results using total non-durable consumption and the full set of exclusion restrictions are reported in Tables B1 and C1 in the Appendix. Those for other specifications of consumption and exclusion restrictions are available from the authors on request. In all cases the likelihood ratio test rejects the null hypothesis of joint statistical

\footnotetext{
${ }^{14}$ We recognize that consumption of alcohol and tobacco is likely to be under-reported (Stockwell et al., 2004) but have no reason to believe that this under-reporting is correlated with under-reporting of income.

${ }^{15}$ Although we use the term "spouse" throughout, explicit marital status cannot be determined from the Czech data, which only reports whether the household head has a life partner, not the exact legal status of the relationship.
} 
Table 1: Summary statistics of the subsample in the Czech HBS, 2008

\begin{tabular}{lcc}
\hline Variable & Mean & Std. Dev. \\
\hline \hline Total no. of households & 2,138 & $\mathrm{~N} / \mathrm{A}$ \\
Household members & 2.606 & 1.192 \\
Economically active & 1.49 & 0.585 \\
Not economically active excl. children & 0.299 & 0.474 \\
Children & 0.817 & 0.943 \\
Heads with a spouse or a partner & 1,486 & $\mathrm{~N} / \mathrm{A}$ \\
Heads with 'maturita'* & 814 & $\mathrm{~N} / \mathrm{A}$ \\
Heads with bachelor's degree and higher & 264 & $\mathrm{~N} / \mathrm{A}$ \\
Spouses with 'maturita'* & 854 & $\mathrm{~N} / \mathrm{A}$ \\
Spouses with bachelor's degree and higher & 174 & $\mathrm{~N} / \mathrm{A}$ \\
Age of head & 45.306 & 11.073 \\
Female heads & 523 & $\mathrm{~N} / \mathrm{A}$ \\
Blue collar heads & 1,170 & $\mathrm{~N} / \mathrm{A}$ \\
Self-employed heads & 456 & $\mathrm{~N} / \mathrm{A}$ \\
Heads in public sector & 610 & $\mathrm{~N} / \mathrm{A}$ \\
Blue collar spouses & 294 & $\mathrm{~N} / \mathrm{A}$ \\
White collar spouses & 737 & $\mathrm{~N} / \mathrm{A}$ \\
Self-employed spouses & 70 & $\mathrm{~N} / \mathrm{A}$ \\
Spouses in public sector & 522 & $\mathrm{~N} / \mathrm{A}$ \\
Monthly expenses on food (CZK**) & 6316.622 & 56.66 \\
Monthly expenses on non-durables (CZK) & $18,710.787$ & $7,094.331$ \\
Monthly disposable income (CZK) & $31,750.111$ & $16,346.241$
\end{tabular}

* 'Maturita' is the high school exit exam taken by students in academic high schools and selected vocational schools. It can be compared to A-level exams in the UK.

** The average exchange rate of the Czech crown to the USD in 2008 was approximately 19.35 CZK/USD. 
Table 2: Summary statistics of the subsample in the Slovak HBS, 2008

\begin{tabular}{|c|c|c|}
\hline Variable & Mean & Std. Dev. \\
\hline "Total number of households in the subsample & 2,885 & $\mathrm{~N} / \mathrm{A}$ \\
\hline Household members & 3.275 & 1.307 \\
\hline Economically active & 1.749 & 0.721 \\
\hline Not economically active excl. children & 0.478 & 0.627 \\
\hline Children & 1.048 & 1.053 \\
\hline Married heads & 2,048 & $\mathrm{~N} / \mathrm{A}$ \\
\hline Heads with 'maturita'* & 1,425 & $\mathrm{~N} / \mathrm{A}$ \\
\hline Heads with bachelor's degree and higher & 457 & $\mathrm{~N} / \mathrm{A}$ \\
\hline Spouses with 'maturita'* & 1,259 & $\mathrm{~N} / \mathrm{A}$ \\
\hline Spouses with bachelor's degree and higher & 295 & $\mathrm{~N} / \mathrm{A}$ \\
\hline Age of head & 44.096 & 9.829 \\
\hline Female heads & 702 & $\mathrm{~N} / \mathrm{A}$ \\
\hline Blue collar heads & 1,192 & $\mathrm{~N} / \mathrm{A}$ \\
\hline Self-employed heads & 483 & $\mathrm{~N} / \mathrm{A}$ \\
\hline Heads in public sector & 761 & $\mathrm{~N} / \mathrm{A}$ \\
\hline Blue collar spouses & 313 & $\mathrm{~N} / \mathrm{A}$ \\
\hline White collar spouses & 2,158 & $\mathrm{~N} / \mathrm{A}$ \\
\hline Self-employed spouses & 116 & $\mathrm{~N} / \mathrm{A}$ \\
\hline Spouses in public sector & 671 & $\mathrm{~N} / \mathrm{A}$ \\
\hline Monthly expenses on food (SKK**) & 6462.602 & 50.139 \\
\hline Monthly expenses on non-durables (SKK $\left.{ }^{* *}\right)$ & $23,925.25$ & $10,110.226$ \\
\hline Monthly disposable income $\left(\mathrm{SKK}^{* *}\right)$ & $33,365.971$ & $12,972.335$ \\
\hline
\end{tabular}


insignificance of estimates at the 1 percent level. ${ }^{16}$ Plugging the estimated structural coefficients into Equation (18) yields the estimates of the shadow economy in Tables 3 and 4 .

The robustness of our results to alternative definitions of consumption (non-durables, food, non-durables minus rents) and different sets of exclusion restrictions including with identification based solely on the functional form is striking. This would imply that slight violations of the homotheticity assumption are not critical for the empirical results. With respect to identification assumptions, although the estimated size of the shadow economy is remarkably close without the exclusion restrictions to those obtained using such restrictions, not surprisingly, it is much more difficult to reach convergence. Identification becomes much easier as more exclusion restrictions are added. ${ }^{17}$

The key finding is that under all alternative specifications, the shadow economy in the Czech Republic is tightly estimated to be between 20 and 22 percent of reported income in 2008, while in Slovakia this fraction is between 25 and 35 percent. Thus, to arrive at true income in these economies, we have to multiply the officially reported income by approximately 1.2 and 1.3 respectively. As can be seen in Table5 these estimates exceed others in the literature, often by a substantial amount. ${ }^{18}$ From these results it is obvious that in post-communist countries at least, under-reporting of income extends to wage and salary workers as well as the self-employed.

Equation (19) enables calculation of the predicted probability of hiding income defined on the interval $[0,1]$ for every household in the sample. As might be expected from Tables 3 and 4, the mean of this estimated probability is substantially higher in Slovakia, where

\footnotetext{
${ }^{16}$ The likelihood ratio test is a natural choice to test the assumption that divided households into two groups based on their consumption-income gaps. Given that a model consisting of a single gap function is nested in the endogenous switching model, such a test can be used to compare the two models, with the null hypothesis being that both models explain data equally well. Following Dickens and Lang (1985), the degrees of freedom are equal to the number of constraints plus the number of unidentified parameters (found only in the switching equation). As argued by Goldfeld and Quandt (1976), this leads to a conservative critical value.

${ }^{17}$ Without any exclusion restrictions, we need to draw more than 50,000 bootstrap samples to gain convergence in 250 cases. With only self-employed and public sector employment dummies for household heads and spouses (if any), the number of samples needed drops to around 1,000. When we add also blue-collar dummy for heads and spouses and white-collar dummy for spouses, this number is further decreased to around 400 .

${ }^{18}$ With the notable exception of Alm and Embaye (2013), whose estimates are uniformly higher than those found elsewhere.
} 


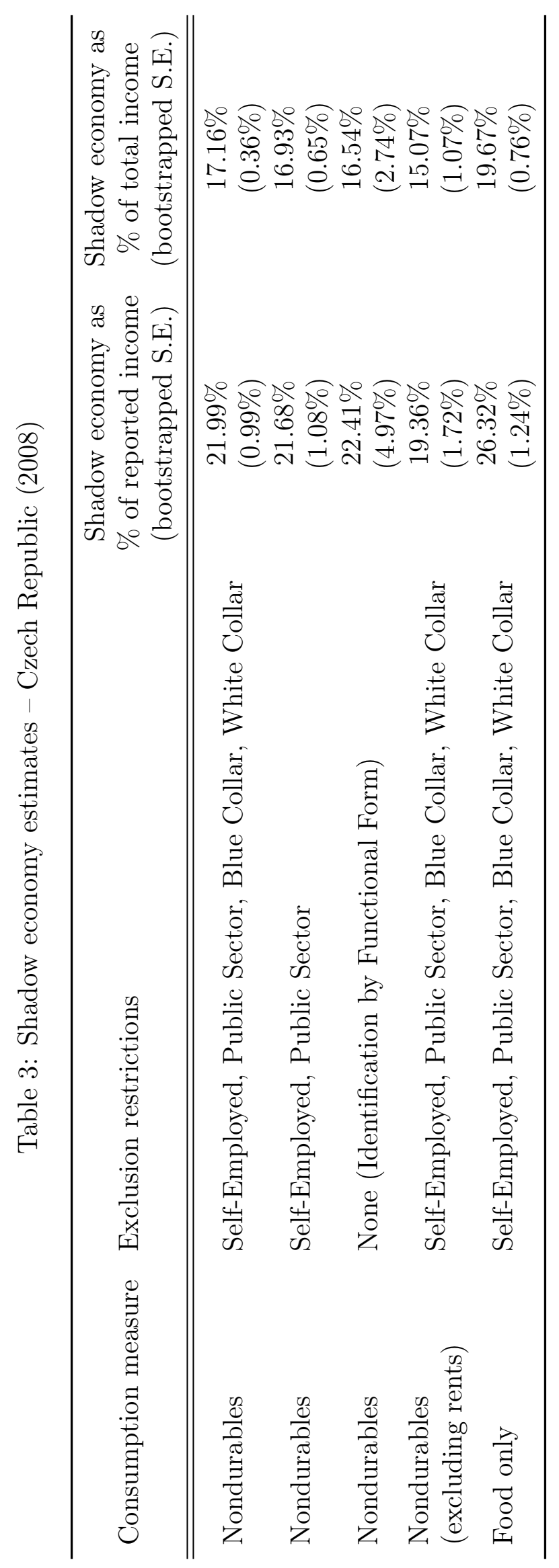




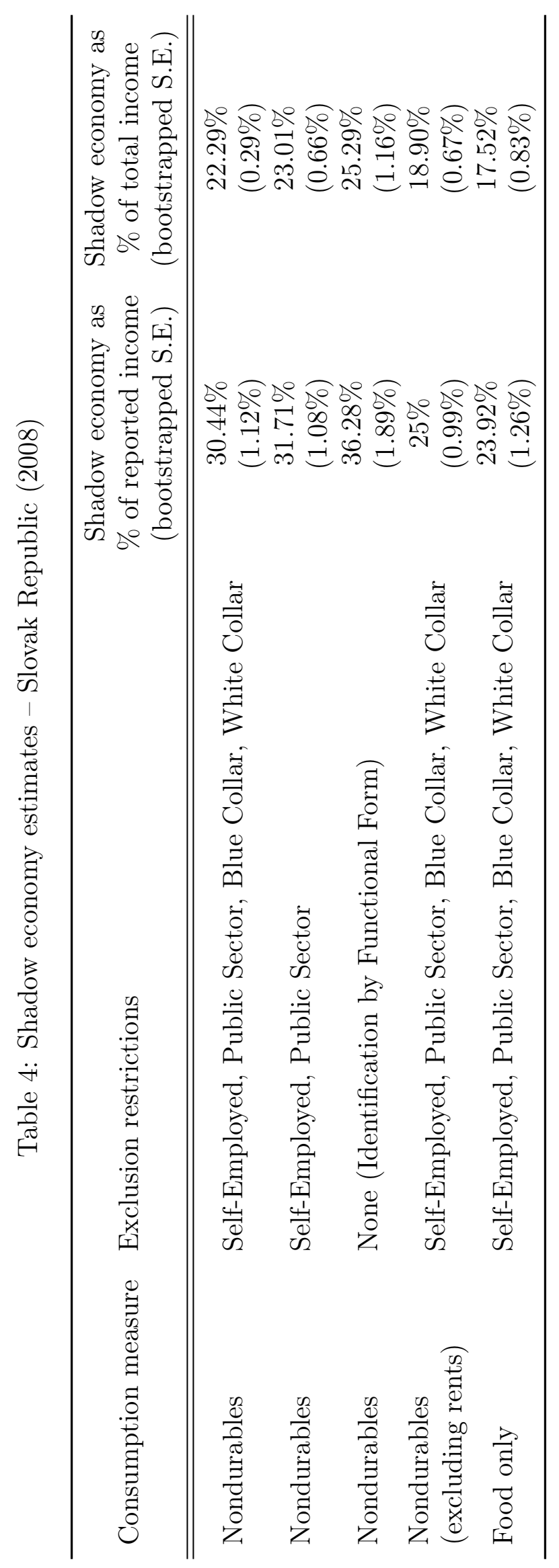




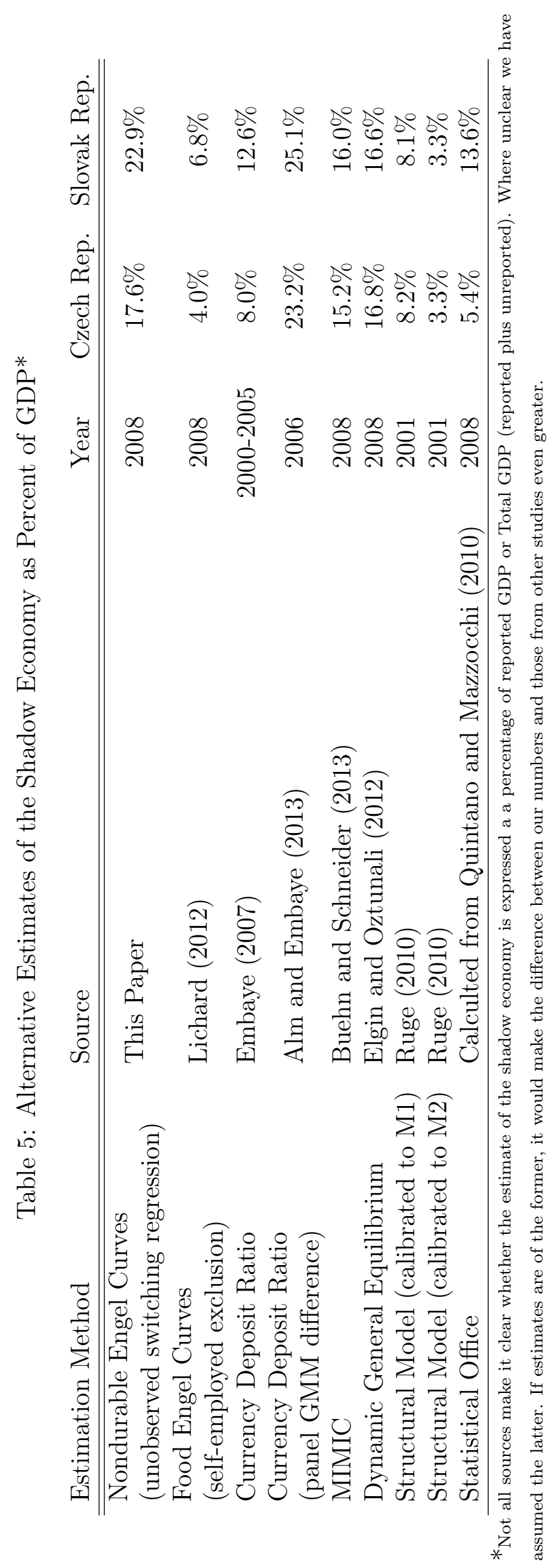


the average household has an estimated 54 percent probability of hiding at least some income, than it is in the Czech Republic, where the corresponding estimated probability is 34 percent. As can be seen in Fig.1, which plots the distribution of probabilities across the samples, there is a bimodal pattern with mass concentrated at or near zero in both countries and then a second concentration at higher probabilities, with the main mass at a substantially higher probability in Slovakia.

Figure 1: Histograms of evasion probabilities

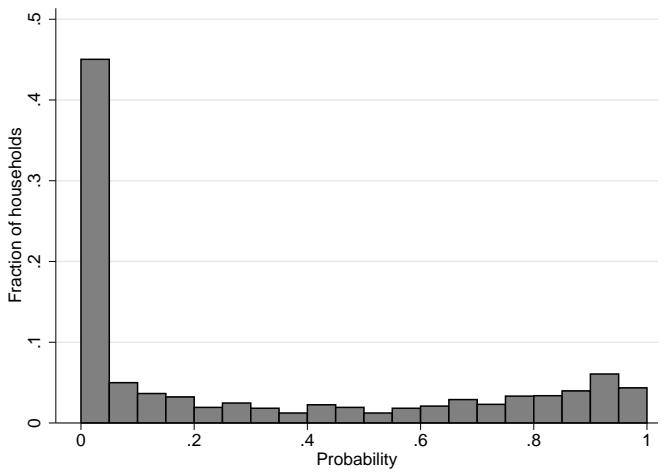

(a) Czech Republic

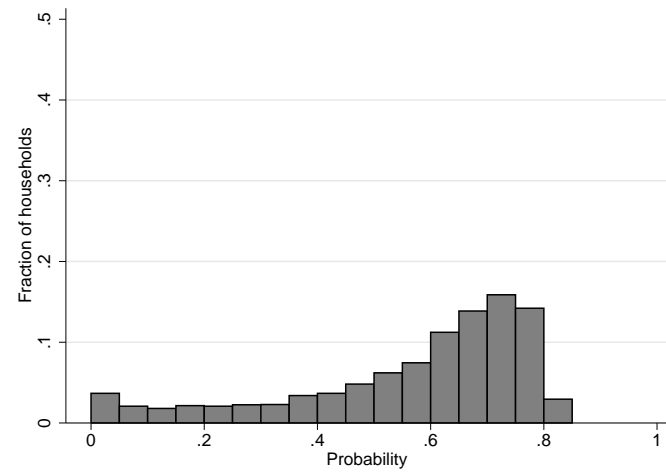

(b) Slovakia

The impact of various factors on the probability of a household under-reporting income (computed for each observation and then averaged) corresponds with intuition as can be seen in Appendix (B2) and (C2). Households headed by women are substantially less likely to under-report income (by 12 percentage points in each country). This result is consistent with previous studies of gender differences in tax evasion (see Baldry, 1987;McGee, 2012). Possible explanations for this finding include gender differences in risk aversion ${ }^{19}$ and the higher frequency with which primarily male household heads are charged with calculating tax reporting forms. The same results are found for married households in Slovakia where households headed by single males are the most likely to under-report.

Job characteristics (blue collar employment, self-employment and working in the public sector) of household heads are uniformly more predictive than that of their spouses, again probably due to greater variation in males' behavior with respect to under-reporting. In both countries households working in the public sector are less likely to hide income

\footnotetext{
${ }^{19}$ Previous studies often find that women are more risk averse than men. See, for example Halek and Eisenhauer (2001) and Eckel and Grossman (2008).
} 
although the effect is higher when the head is so employed than the spouse. Results with respect to self-employment are somewhat puzzling. Such status, as expected, has a substantial effect for both household heads and their spouses in Slovakia while in the Czech Republic both effects are actually negative, posing an obvious question for further research. In both countries households headed by blue-collar workers (or containing spouses with blue-collar jobs) are less likely to under-report. Workers with high school degrees are less likely to under-report than those with either more or less education.

These results suggest that, in addition to being greater in overall magnitude, the propensity to under-report income is more generalized in Slovakia than in the Czech Republic. The findings with respect to both extent and composition of under-reporting are consistent with the overall level of economic development in Slovakia. In 2008, when our data was collected, GDP per capita was 75 percent greater in the Czech Republic than in Slovakia $(\$ 23,833$ as opposed to $\$ 13,603)$. Schneider (2012) reports that, among OECD countries, lower GDP per capita is associated with a higher propensity to work in the shadow economy. Similarly,Williams (2013) reports that undeclared envelope wages are more common in poorer nations. ${ }^{20}$

\section{Conclusion}

The size of the shadow economy was estimated based on microeconomic data without imposing the unrealistic assumptions that have hampered previous estimators and are likely to have led to under-estimating the size of the shadow economy by excluding underreporting among a group that was unjustifiably assumed to fully report their income. The application of this methodology to Czech and Slovak data yields estimates of the size of the shadow economy that are substantially larger than those obtained from other methodologies (both macroeconomic techniques and microeconomic ones using standard techniques). The logical explanation is that employees being paid under the table or having a secondary, undeclared, source of income while not being officially classified as

\footnotetext{
${ }^{20} \mathrm{An}$ alternative explanation might be that in 2008 cash register receipts were required for all transactions in the Czech Republic (introduced in 2007) while a similar reform was not introduced in Slovakia until 2011. Both countries had moved from a progressive to a flat tax before 2008.
} 
"self-employed" constitute a major source of unreported income. Excluding the possibility of such hidden income can result in serious under-estimation of the size of the shadow economy and distortions in observed income distributions with important policy implications. 


\section{References}

Allingham, M. G., \& Sandmo, A. (1972). Income tax evasion: A theoretical analysis. Journal of Public Economics, 1(3-4), 323-338.

Alm, J., \& Embaye, A. (2013). Using dynamic panel methods to estimate shadow economies around the world, 1984-2006. Public Finance Review, 41(5), 510-543.

Alzua, M. L. (2009). Are secondary workers informal workers?: Evidence for Argentina. Desarrollo y Sociedad, 81-114.

Arunachalam, R., \& Logan, T. D. (2006, October). On the heterogeneity of dowry motives (Working Paper No. 12630). National Bureau of Economic Research.

Baldry, J. C. (1987). Income tax evasion and the tax schedule: Some experimental results. Public Finance $=$ Finances publiques, 42(3), 357-83.

Braguinsky, S., Mityakov, S., \& Liscovich, A. (2014). Direct estimation of hidden earnings: Evidence from Russian administrative data. Journal of Law and Economics, 57(2), $281-319$.

Brewer, M., \& O'Dea, C. (2012). Measuring living standards with income and consumption: evidence from the UK (Working Paper No. 2012-5). ISER.

Brzozowski, M., \& Crossley, T. F. (2011). Viewpoint: Measuring the well-being of the poor with income or consumption: a Canadian perspective. Canadian Journal of Economics/Revue canadienne d'économique, 44(1), 88-106.

Buehn, A., \& Schneider, F. (2013, August). Shadow economies in highly developed OECD countries: What are the driving forces? (Working Paper No. 1317). Department of Economics, Johannes Kepler University of Linz.

Cagan, P. (1958). The demand for currency relative to total money supply. NBER.

Caudill, S. B. (2003). Estimating a mixture of stochastic frontier regression models via the EM algorithm: A multiproduct cost function application. Empirical Economics, $28(3), 581-598$.

Clementi, F., \& Gallegati, M. (2005). Pareto's law of income distribution: Evidence for Germany, the United Kingdom, and the United States. In A. Chatterjee, S. Yarlagadda, \& B. K. Chakrabarti (Eds.), Econophysics of wealth distributions (pp. 3-14). 
Springer Milan.

Davutyan, N. (2008). Estimating the size of Turkey's informal sector: An expenditurebased approach. Journal of Economic Policy Reform, 11(4), 261-271.

DeCicca, P., Kenkel, D. S., \& Liu, F. (2010, April). Excise tax avoidance: The case of state cigarette taxes (Working Paper No. 15941). National Bureau of Economic Research.

Dickens, W. T., \& Lang, K. (1985). A test of dual labor market theory. The American Economic Review, 75(4), 792-805.

Douglas, S. M., Conway, K. S., \& Ferrier, G. D. (1995). A switching frontier model for imperfect sample separation information: With an application to constrained labor supply. International Economic Review, 36(2), 503-526.

Dreher, A., Méon, P.-G., \& Schneider, F. (2014). The devil is in the shadow. Do institutions affect income and productivity or only official income and official productivity? Public Choice, 158(1-2), 121-141.

Dutoit, L. C. (2007). Heckman's selection model, endogenous and exogenous switching models: A survey. The Selected Works of Laure C. Dutoit. Available at: http://works.bepress.com/laure_dutoit/3.

Eckel, C. C., \& Grossman, P. J. (2008). Men, women and risk aversion: Experimental evidence. In C. R. Plott \& V. L. Smith (Eds.), Handbook of experimental economics results (p. 1061 - 1073). Elsevier.

Eichenbaum, M., \& Hansen, L. P. (1990). Substitution using time with intertemporal aggregate series data. Journal of Business 86 Economic Statistics, 8(1), 53-69.

Ekici, T., \& Besim, M. (2014). A measure of the shadow economy in a small economy: Evidence from household-level expenditure patterns. Review of Income and Wealth.

Elgin, C., \& Oztunali, O. (2012). Shadow economies around the world: Model based estimates (Working Paper No. 2012/5). Bogazici University.

Elgin, C., \& Uras, B. R. (2013). Public debt, sovereign default risk and shadow economy. Journal of Financial Stability, 9(4), 628-640.

Embaye, A. (2007). Underground economy estimates for non-oecd countries using currency 
demand method, 1984-2005 (MPRA Paper No. 20308). Munich Personal RePEc Archive.

Engström, P., \& Holmlund, B. (2009). Tax evasion and self-employment in a high-tax country: Evidence from Sweden. Applied Economics, 41(19), 2419-2430.

European Commission. (2007). Undeclared work in the European Union. Special Eurobarometer, 284.

Friedman, M. (1957). The relation between the permanent income and relative income hypotheses. In A theory of the consumption function (p. 157-182). Princeton University Press.

Goldfeld, S. M., \& Quandt, R. E. (1976). Techniques for estimating switching regressions. In Studies in nonlinear estimation (pp. 3-35). Cambridge, MA: Ballinger.

Gorodnichenko, Y., Martinez-Vazquez, J., \& Sabirianova Peter, K. (2009). Myth and reality of flat tax reform: Micro estimates of tax evasion response and welfare effects in Russia. Journal of Political Economy, 117(3), 504-554.

Guiso, L., Sapienza, P., \& Zingales, L. (2013). Time varying risk aversion (Working Paper No. 19284). National Bureau of Economic Research.

Gunes, A. T. A., Starzec, C., \& Gardes, F. (2013). A new estimation of the size of informal economy using monetary and full expenditures in a complete demand system (Working Paper No. 2013.53). Centre d'Economie de la Sorbonne.

Halek, M., \& Eisenhauer, J. G. (2001). Demography of risk aversion. Journal of Risk and Insurance, $1-24$.

Hanousek, J., \& Palda, F. (2006). Problems measuring the underground economy in transition. Economics of Transition, 14(4), 707-718.

Harberger, A. (1964). Taxation, resource allocation, and welfare. In The role of direct and indirect taxes in the federal reserve system (p. 25-80). Princeton University Press.

Hurst, E., Li, G., \& Pugsley, B. (2014). Are household surveys like tax forms? Evidence from income underreporting of the self-employed. Review of Economics and Statistics, 96(1), 19-33.

Kim, C.-J., Piger, J., \& Startz, R. (2008). Estimation of Markov regime-switching 
regression models with endogenous switching. Journal of Econometrics, 143(2), $263-273$.

Kolm, A.-S., \& Nielsen, S. B. (2008). Under-reporting of income and labor market performance. Journal of Public Economic Theory, 10(2), 195-217.

Kopczuk, W., \& Lupton, J. P. (2007). To leave or not to leave: The distribution of bequest motives. The Review of Economic Studies, 74 (1), 207-235.

Kreiner, C. T., Lassen, D. D., \& Leth-Petersen, S. r. (2013). Measuring the accuracy of survey responses using administrative register data: Evidence from Denmark (Working Paper No. 19539). National Bureau of Economic Research.

Kukk, M., \& Staehr, K. (2014). Income underreporting by households with business income: Evidence from Estonia. Post-Communist Economies, 26 (2), 257-276.

Lee, L.-F., \& Porter, R. H. (1984). Switching regression models with imperfect sample separation information-With an application on cartel stability. Econometrica, 52(2), 391-418.

Lichard, T. (2012). Shadow economy in the Czech republic, Russia, Slovakia and Ukraine: Food Engel curve approach. (Unpublished manuscript)

Lyssiotou, P., Pashardes, P., \& Stengos, T. (2004). Estimates of the black economy based on consumer demand approaches. Economic Journal, 114(497), 622-640.

Maddala, G. S. (1983). Limited-dependent and qualitative variables in econometrics (No. 3). Cambridge: Cambridge University Press.

Martinez-Lopez, D. (2012). The underreporting of income by self-employed workers in Spain. SERIEs, 4(4), 353-371.

McGee, R. W. (2012). Gender and the ethics of tax evasion: An empirical study of 82 countries. In R. W. McGee (Ed.), The ethics of tax evasion (p. 415-439). Springer New York.

Meyer, B. D., \& Sullivan, J. X. (2013). Winning the war: Poverty from the Great Society to the Great Recession (Working Paper No. 18718). National Bureau of Economic Research.

Ogaki, M., \& Reinhart, C. M. (1998). Measuring intertemporal substitution: The role of 
durable goods. Journal of Political Economy, 106, 1078-1098.

Pakoš, M. (2011). Estimating intertemporal and intratemporal substitutions when both income and substitution effects are present: The role of durable goods. Journal of Business 6 Economic Statistics, 29(3), 439-454.

Pissarides, C. A., \& Weber, G. (1989). An expenditure-based estimate of Britain's black economy. Journal of Public Economics, 39(1), 17-32.

Putniņš, T. J., \& Sauka, A. (2014). Measuring the shadow economy using company managers. Journal of Comparative Economics. (In Press)

Quintano, C., \& Mazzocchi, P. (2010). Some alternative estimates of underground economies in 12 new eu member states. International Economic Journal, 24(4), $611-628$.

Ruge, M. (2010). Determinants and size of the shadow economy-a structural equation model. International Economic Journal, 24(4), 511-523.

Saez, E., Slemrod, J., \& Giertz, S. H. (2012). The elasticity of taxable income with respect to marginal tax rates: A critical review. Journal of Economic Literature, $50(1), 3-50$.

Schneider, F. (2012, March). The shadow economy and work in the shadow: What do we (not) know? (Discussion Paper No. 6423). IZA.

Schneider, F. (2014, June). The shadow economy and shadow labor force: A survey of recent developments (Working Paper No. 8278). IZA.

Schneider, F., \& Enste, D. H. (2002). The shadow economy: An international survey. Cambridge (UK): Cambridge University Press.

Schuetze, H. J. (2002). Profiles of tax non-compliance among the self-employed in Canada: 1969 to 1992. Canadian Public Policy/Analyse de Politiques, 219-238.

Slemrod, J. (2007). Cheating ourselves: The economics of tax evasion. The Journal of Economic Perspectives, 21(1), 25-48.

Slemrod, J., Blumenthal, M., \& Christian, C. (2001). Taxpayer response to an increased probability of audit: Evidence from a controlled experiment in Minnesota. Journal of Public Economics, $79(3), 455-483$. 
Slemrod, J., \& Weber, C. (2012). Evidence of the invisible: toward a credibility revolution in the empirical analysis of tax evasion and the informal economy. International Tax and Public Finance, 19(1), 25-53.

Stockwell, T., Donath, S., Cooper-Stanbury, M., Chikritzhs, T., Catalano, P., \& Mateo, C. (2004). Under-reporting of alcohol consumption in household surveys: A comparison of quantity-frequency, graduated-frequency and recent recall. Addiction, 99(8), $1024-33$.

Tedds, L. M. (2010). Estimating the income reporting function for the self-employed. Empirical Economics, 38(3), 669-687.

Thomas, J. (1999). Quantifying the black economy: 'measurement without theory' yet again? The Economic Journal, 109(456), 381-389.

Warren, R. P. (1946). All the king's men. New York: Harcourt, Brace.

Williams, C. C. (2013). Evaluating cross-national variations in the extent and nature of informal employment in the european union. Industrial Relations Journal, 44 (5-6), 479-494. 


\section{A Technical Appendix}

The estimation was done in TSP 5.1 (64-bit) via the command 'ml'. This command maximizes the log-likelihood function numerically ${ }^{21}$ and, therefore, choosing appropriate initial values is essential for convergence. The initial values were set by a procedure described in Dutoit (2007). We initially separate the sample through a dummy $I_{i}=1$ if the household $i$ 's gap is above a certain threshold (creating an initial group presumed to be evading) or $I_{i}=0$ if it is below that threshold (initially assumed non-evading group). To obtain initial values of $\boldsymbol{\delta}$, a probit regression of $I_{i}$ on $\mathbf{Z}_{i}$ is run. After that we use these estimated values $(\hat{\delta})$ to obtain initial values of the $\boldsymbol{\beta}$ 's by running the following OLS regressions:

$$
\ln C_{i}-\ln Y_{i}=\mathbf{X}_{i} \boldsymbol{\beta}_{e}-\sigma_{e, s} \frac{\phi\left(\mathbf{Z}_{i} \hat{\boldsymbol{\delta}}\right)}{\Phi\left(\mathbf{Z}_{i} \hat{\boldsymbol{\delta}}\right)}+\varepsilon_{i, e} \text { if } I_{i}=1
$$

and

$$
\ln C_{i}-\ln Y_{i}=\mathbf{X}_{i} \boldsymbol{\beta}_{n e}+\sigma_{n e, s} \frac{\phi\left(\mathbf{Z}_{i} \hat{\boldsymbol{\delta}}\right)}{1-\Phi\left(\mathbf{Z}_{i} \hat{\boldsymbol{\delta}}\right)}+\varepsilon_{i, n e} \text { if } I_{i}=0
$$

Then we get initial values of $\sigma_{e}$ and $\sigma_{e, s}$ by running the following OLS estimation:

$$
\hat{u}_{e, i}^{2}=\sigma_{e}^{2}-\sigma_{e, s} \frac{\phi\left(\mathbf{Z}_{i} \hat{\boldsymbol{\delta}}\right)}{\Phi\left(\mathbf{Z}_{i} \hat{\boldsymbol{\delta}}\right)}
$$

where $\hat{u}_{e, i}=\left(\ln C_{i}-\ln Y_{i}\right)-X_{i} \hat{\beta}_{e}$, where $\hat{\beta}_{e}$ is the estimate of $\beta_{e}$ coming from Equation(22). The initial values of $\sigma_{n e}$ and $\sigma_{n e, s}$ are obtained analogously by running:

$$
\hat{u}_{n e, i}^{2}=\sigma_{n e}^{2}-\sigma_{n e, s} \frac{\phi\left(\mathbf{Z}_{i} \hat{\boldsymbol{\delta}}\right)}{1-\Phi\left(\mathbf{Z}_{i} \hat{\boldsymbol{\delta}}\right)} .
$$

These initial values of $\delta, \boldsymbol{\beta}$ 's and $\sigma$ 's are used as starting values for the numerical optimization procedure.

\footnotetext{
${ }^{21}$ For more detailed information on this command including stopping rules, see the TSP manual at http://www.tspintl.com/products/manuals.htm.
} 
To make the results robust, for each random sample within the Monte Carlo simulation the initial sample separation is in turn set to the first, second and third quartiles, and the mean of the consumption-income gap of the given Monte Carlo sample. After applying the above procedure to each of these initial splits, we choose the results of the one that yields the highest log-likelihood as the final results for the given sample. This process results in the data series from which statistics such as the estimated size of shadow economy and its standard error are computed. 


\section{B Estimation Results - Czech Republic}

Table B1: Structural model coefficients - Czech Republic (2008)

\begin{tabular}{|c|c|c|c|c|c|c|}
\hline \multirow{2}{*}{$\begin{array}{l}\text { VARIABLES } \\
\text { constant }\end{array}$} & \multicolumn{2}{|c|}{$\begin{array}{c}\text { Shadow sector } \\
\ln C-\ln Y\end{array}$} & \multicolumn{2}{|c|}{$\begin{array}{c}\text { Official sector } \\
\ln C-\ln Y\end{array}$} & \multicolumn{2}{|c|}{$\begin{array}{c}\text { Switching equation } \\
\text { Latent variable }\end{array}$} \\
\hline & $-0.452^{* * *}$ & $(0.012)$ & $0.264^{* * *}$ & $(0.637)$ & $3.061^{* * *}$ & $(0.459)$ \\
\hline \# of children & -0.000 & $(0.001)$ & 0.007 & $(0.007)$ & & \\
\hline \# of employed & 0.000 & $(0.002)$ & $-0.034^{* * *}$ & $(0.012)$ & & \\
\hline \# of unemployed & $0.004^{* *}$ & $(0.002)$ & $-0.054^{* * *}$ & $(0.015)$ & & \\
\hline is married & 0.003 & $(0.004)$ & 0.097 & $(0.608)$ & $-1.045^{* *}$ & $(0.434)$ \\
\hline high school degree & -0.000 & $(0.003)$ & -0.018 & $(0.017)$ & -0.010 & $(0.029)$ \\
\hline bachelor's degree or higher & $-0.007 * * *$ & $(0.002)$ & $-0.047^{*}$ & $(0.027)$ & $0.108^{* * *}$ & $(0.039)$ \\
\hline high school degree (spouse) & 0.003 & $(0.003)$ & 0.046 & $(0.029)$ & $-0.071^{*}$ & $(0.041)$ \\
\hline bachelor's degree or higher (spouse) & 1.242 & $(1.419)$ & -0.080 & $(0.151)$ & 0.867 & $(1.044)$ \\
\hline age & 0.001 & $(0.000)$ & $0.010^{*}$ & $(0.005)$ & $-0.029 * * *$ & $(0.007)$ \\
\hline $\operatorname{age}^{2}$ & -0.000 & $(0.000)$ & $-0.001^{*}$ & $(0.001)$ & $-0.000^{* * *}$ & $(0.000)$ \\
\hline hoh is female & 0.001 & $(0.004)$ & 0.072 & $(0.610)$ & $-1.021^{* *}$ & $(0.432)$ \\
\hline has children & & & & & -0.000 & $(0.022)$ \\
\hline blue collar & & & & & -0.012 & $(0.016)$ \\
\hline works in public sector & & & & & 0.028 & $(0.017)$ \\
\hline self-employed & & & & & 0.026 & $(0.018)$ \\
\hline spouse in public sector & & & & & 0.010 & $(0.022)$ \\
\hline white collar spouse & & & & & 0.043 & $(0.028)$ \\
\hline blue collar spouse & & & & & 0.040 & $(0.034)$ \\
\hline self-employed spouse & & & & & 0.945 & $(0.675)$ \\
\hline$\sigma_{1}$ & $0.286^{* * *}$ & $(0.001)$ & & & & \\
\hline$\sigma_{2}$ & & & $0.847^{* * *}$ & $(0.017)$ & & \\
\hline$\sigma_{13}$ & & & & & $0.254^{* * *}$ & $(0.004)$ \\
\hline$\sigma_{23}$ & & & & & $-0.721^{* * *}$ & $(0.030)$ \\
\hline Observations & & & 2,1 & & & \\
\hline Log likelihood & & & -342 & & & \\
\hline LR test & & & 598 & & & \\
\hline $\operatorname{Prob}>\chi^{2}(40)$ & & & 0.00 & & & \\
\hline
\end{tabular}

Bootstrapped standard errors in parentheses: ${ }^{* * *} \mathrm{p}<0.01,{ }^{* *} \mathrm{p}<0.05,{ }^{*} \mathrm{p}<0.1$. The structural coefficients for consumptionincome gap equations express also the marginal effects given variables have on consumption-income gap. The structural coefficients for switching equation do not have a straightforward interpretation. The marginal effects on probability are shown in Table B2. 
Table B2: Marginal effects - Czech Republic

\begin{tabular}{lr}
\hline & $\begin{array}{c}\text { Probability of being } \\
\text { VARIABLES }\end{array}$ \\
& in the shadow sector \\
is married & 0.009 \\
age & 0.039 \\
age $^{2}$ & -0.000 \\
female & -0.124 \\
has children & 0.045 \\
high school degree & -0.081 \\
bachelor's degree or higher & -0.047 \\
high school degree (spouse) & 0.032 \\
bachelor's degree or higher (spouse) & 0.061 \\
blue collar & -0.009 \\
self-employed & -0.059 \\
works in public sector & -0.015 \\
blue collar spouse & -0.004 \\
white collar spouse & 0.058 \\
self-employed spouse & -0.006 \\
spouse in public sector & -0.006 \\
\hline
\end{tabular}

The average marginal effects were computed as the average of marginal effects predicted for every observation in the subsample. 


\section{Estimation Results - Slovak Republic}

Table C1: Structural model coefficients - Slovak Republic (2008)

\begin{tabular}{|c|c|c|c|c|c|c|}
\hline \multirow{2}{*}{$\begin{array}{l}\text { VARIABLES } \\
\text { constant }\end{array}$} & \multicolumn{2}{|c|}{$\begin{array}{c}\text { Evading regime } \\
\ln C-\ln Y\end{array}$} & \multicolumn{2}{|c|}{$\begin{array}{c}\text { Non-evading regime } \\
\quad \ln C-\ln Y\end{array}$} & \multicolumn{2}{|c|}{$\begin{array}{c}\text { Switching equation } \\
\text { N/A (latent) }\end{array}$} \\
\hline & $-0.167 * * *$ & $(0.069)$ & -0.132 & $(0.139)$ & $-2.751^{* * *}$ & $(0.828)$ \\
\hline \# of children & $-0.008^{* * *}$ & $(0.002)$ & $-0.019 * * *$ & $(0.001)$ & & \\
\hline \# of employed & $-0.113^{* * *}$ & $(0.002)$ & $-0.080^{* * *}$ & $(0.002)$ & & \\
\hline \# of unemployed & $-0.038^{* * *}$ & $(0.002)$ & $-0.046^{* * *}$ & $(0.002)$ & & \\
\hline is married & $0.025^{* * *}$ & $(0.0048)$ & $-0.050^{* * *}$ & $(0.0120)$ & $0.021^{* * *}$ & -0.004 \\
\hline high school degree & $0.038^{* * *}$ & $(0.013)$ & $0.042^{* * *}$ & $(0.005)$ & $-0.180^{* * *}$ & $(0.037)$ \\
\hline bachelor's degree or higher & 0.012 & $(0.013)$ & $-0.050^{* * *}$ & $(0.011)$ & $-0.209^{* * *}$ & $(0.039)$ \\
\hline high school degree (spouse) & -0.007 & $(0.010)$ & -0.041 & $(0.126)$ & 0.058 & $(0.125)$ \\
\hline bachelor's degree or higher (spouse) & $-0.116^{* * *}$ & $(0.017)$ & -0.016 & $(1.355)$ & -0.007 & $(0.933)$ \\
\hline age & $0.005^{*}$ & $(0.003)$ & $-0.021^{* * *}$ & $(0.002)$ & $0.128^{* * *}$ & $(0.011)$ \\
\hline $\operatorname{age}^{2}$ & 0.000 & $(0.000)$ & 0.000 & $(0.000)$ & $-0.001^{* * *}$ & $(0.000)$ \\
\hline female & 0.001 & $(0.011)$ & $0.050^{* * *}$ & $(0.007)$ & 0.037 & $(0.743)$ \\
\hline has children & & & & & $0.165^{* * *}$ & $(0.017)$ \\
\hline blue collar & & & & & $-0.035^{* * *}$ & $(0.013)$ \\
\hline works in public sector & & & & & $-0.056^{* * *}$ & $(0.010)$ \\
\hline self-employed & & & & & $-0.218^{* * *}$ & $(0.026)$ \\
\hline blue collar spouse & & & & & -0.013 & $(0.760)$ \\
\hline white collar spouse & & & & & 0.212 & $(1.229)$ \\
\hline spouse in public sector & & & & & -0.021 & $(0.019)$ \\
\hline self-employed spouse & & & & & -0.021 & $(0.932)$ \\
\hline$\sigma_{1}$ & $0.250^{* * *}$ & $(0.001)$ & & & & \\
\hline$\sigma_{2}$ & & & $0.547^{* * *}$ & $(0.009)$ & & \\
\hline$\sigma_{13}$ & & & & & $0.184^{* * *}$ & $(0.022)$ \\
\hline$\sigma_{23}$ & & & & & $0.487^{* * *}$ & $(0.023)$ \\
\hline Observations & & & 2,8 & & & \\
\hline Log likelihood & & & -510 & & & \\
\hline LR test & & & 4340 & & & \\
\hline Prob $>\chi^{2}(40)$ & & & 0.00 & & & \\
\hline
\end{tabular}

Bootstrapped standard errors in parentheses: ${ }^{* *} \mathrm{p}<0.01,{ }^{* *} \mathrm{p}<0.05,{ }^{*} \mathrm{p}<0.1$. The structural coefficients for consumptionincome gap equations express also the marginal effects given variables have on consumption-income gap. The structural coefficients for switching equation do not have a straightforward interpretation. The marginal effects on probability are shown in Table C2. 
Table C2: Marginal effects - Slovak Republic (2008)

\begin{tabular}{lr}
\hline & $\begin{array}{c}\text { Probability of being } \\
\text { VARIABLES }\end{array}$ \\
\hline & \\
is married & -0.125 \\
age & 0.044 \\
age & -0.000 \\
female & -0.124 \\
has children & -0.017 \\
high school degree & -0.073 \\
bachelor's degree or higher & -0.015 \\
high school degree (spouse) & 0.050 \\
bachelor's degree or higher (spouse) & 0.089 \\
blue collar & -0.075 \\
self-employed & 0.152 \\
works in public sector & -0.050 \\
blue collar spouse & -0.018 \\
white collar spouse & -0.010 \\
self-employed spouse & 0.087 \\
spouse in public sector & -0.008
\end{tabular}

The average marginal effects were computed as the average of marginal effects predicted for every observation in the subsample. 


\section{Working Paper Series}

ISSN 1211-3298

Registration No. (Ministry of Culture): E 19443

Individual researchers, as well as the on-line and printed versions of the CERGE-EI Working Papers (including their dissemination) were supported from institutional support RVO 67985998 from Economics Institute of the ASCR, v. v. i.

Specific research support and/or other grants the researchers/publications benefited from are acknowledged at the beginning of the Paper.

(c) Tomáš Lichard, Jan Hanousek and Randall K. Filer, 2013

All rights reserved. No part of this publication may be reproduced, stored in a retrieval system or transmitted in any form or by any means, electronic, mechanical or photocopying, recording, or otherwise without the prior permission of the publisher.

Published by

Charles University in Prague, Center for Economic Research and Graduate Education (CERGE) and

Economics Institute of the ASCR, v. v. i. (EI)

CERGE-El, Politických vězňů 7, 11121 Prague 1, tel.: +420 224005 153, Czech Republic.

Printed by CERGE-EI, Prague

Subscription: CERGE-EI homepage: http://www.cerge-ei.cz

Phone: + 420224005153

Email: office@cerge-ei.cz

Web: http://www.cerge-ei.cz

Editor: Michal Kejak

The paper is available online at http://www.cerge-ei.cz/publications/working_papers/.

ISBN 978-80-7343-298-0 (Univerzita Karlova. Centrum pro ekonomický výzkum a doktorské studium)

ISBN 978-80-7344-290-3 (Akademie věd České republiky. Národohospodářský ústav) 
CERGE-EI

P.O.BOX 882

Politických vězňů 7

11121 Praha 1

Czech Republic http://www.cerge-ei.cz 